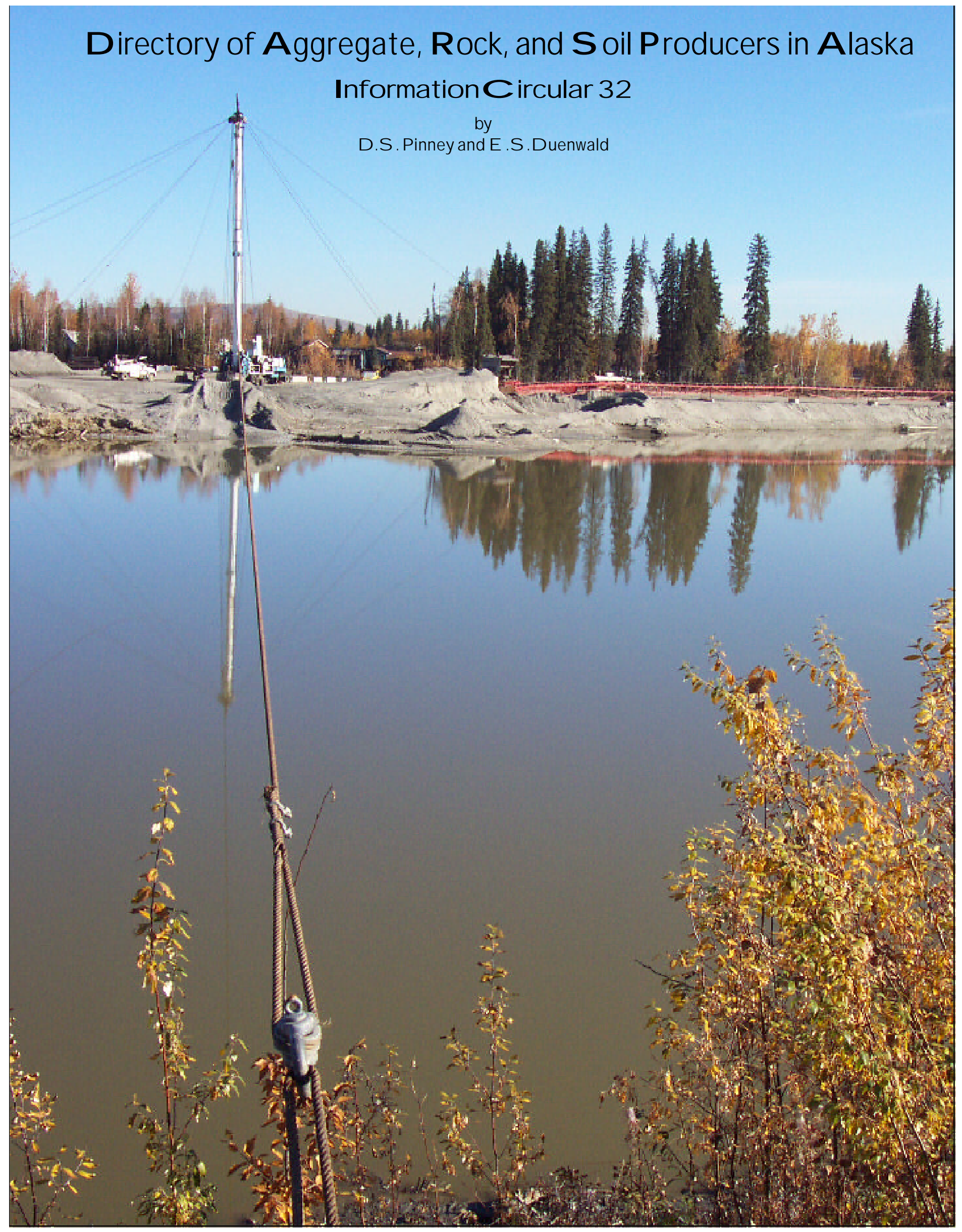

State of Alaska DIVISION OF GEOLOGICAL \& GEOPHYSICAL SURVEYS October 2001 


\title{
DIRECTORY OF AGGREGATE, ROCK, AND SOIL PRODUCERS IN ALASKA
}

\author{
By \\ De Anne S. Pinney ${ }^{1}$ and Emily S. Duenwald ${ }^{1}$
}

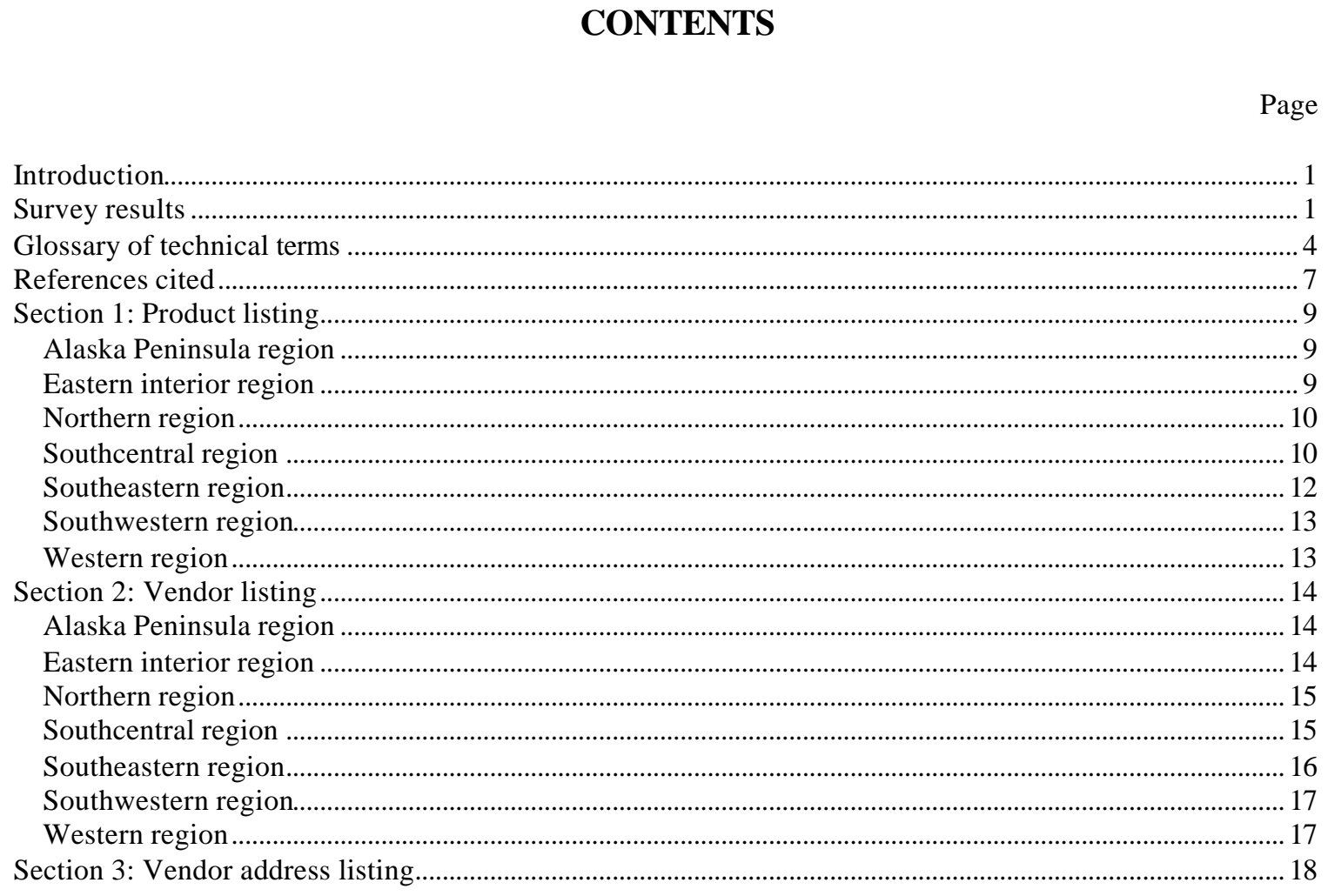

\section{FIGURE}

Figure 1. Map showing locations of regional subdivisions of Alaska................................. 3

TABLE

Table 1. Regional distribution of vendors providing 31 categories of aggregate, rock, and soil products in Alaska....

\footnotetext{
${ }^{1}$ Alaska Division of Geological \& Geophysical Surveys
} 


\section{INTRODUCTION}

Since 1981, the Alaska Division of Geological \& Geophysical Surveys has published for public use general information on the volumes and values of sand and gravel and other rock materials produced annually in Alaska (Bundtzen and others, 1982, 1983, 1984, 1986, 1987, 1988, 1990, 1991, 1994, 1996; Eakins and others, 1983, 1985; Green and others, 1989; Swainbank and others, 1991, 1993, 1995, 1997, 1998, 2000; Szumigala and Swainbank, 1999). The first DGGS directory of aggregate, rock, and soil producers was originally compiled in 1990 in response to a need for current information on active materials vendors. Increased development and growing population requires concurrent expansion of infrastructure that will generate an ever-greater need for construction materials throughout the state. Each year, we receive numerous requests for information on suppliers of various aggregate, rock, and soil products in our state. The purpose of this updated directory is to help potential customers locate active vendors of these materials.

\section{SURVEY RESULTS}

For the purposes of this compilation, Alaska is divided into eight regions (fig. 1). We developed a questionnaire to collect basic information on the types of materials being produced in our state by industrial organizations identified during a survey of telephone directories and direct telephone contacts. Approximately 1200 potential vendors were identified based on listings that included excavating contractors, building contractors, sand and gravel producers, and landscapers. We contacted these companies by telephone to determine if they were producers of the materials types targeted by this survey. We then asked those who confirmed their involvement with mining or producing construction materials to participate in our survey. Companies who expressed a willingness to take part in the study were mailed the questionnaire, consisting of a letter stating the purpose of the survey, a form for contact information and general land ownership and extraction information, and a form for commodity types and volumes. Companies had the option of designating their production information as confidential, in which case their responses would not be made public. Confidential production information is used only in calculations of regional production values, and is not attributed to individual companies. Since the purpose of this survey was to identify private vendors, we did not send questionnaires to major land holders or government entities, even though many sell or produce aggregate, rock, and soil materials.

Of the approximately 1200 companies originally identified, we were unable to contact 195 (16.25 percent). We made at least three attempts to contact every vendor. About 880 companies (73.3 percent) received their materials from other sources and were not directly involved in the extraction or production of construction materials. Of the remaining 125 vendors initially identified, 109 (87.2 percent) expressed an interest in taking part in the survey, and 29 ( 23.2 percent) ultimately responded by completing the forms and returning them. The original response deadline of June 1, 2001, was extended to June 26, 2001, in order to give companies additional time to reply.

We entered data from each response into an Access database for storage, sorting, and retrieval. On the basis of information received from these active producers, we identified vendors for 31 categories of sand-andgravel, rock, soil, and related products in each region, as well as instances where no vendors are known, or where vendors exist but are not currently in production for any materials (table 1). In cases where we know that certain vendors produce materials that they did not indicate, such as placer metals (byproducts), we have not listed these items.

The greatest selection of products and vendors exists in the eastern interior and southcentral regions. In contrast, no private vendors are headquartered in the Alaska Peninisula or western regions, and the northern region is serviced by only one private vendor that is headquartered in the southcentral region. 
Material categories for which very few (one to two) active vendors have been identified include generalized aggregate, armor rock, asphalt, asphalt concrete, base course, concrete sand, crushed asphalt, filter sand, oversize, peat, pre-cast concrete, shot rock, and tailings. Other vendors undoubtedly offer these products but did not respond to our survey.

The first section of this directory lists vendors providing each of the 31 categories of materials in each region; categories for which no vendor has been identified are also shown. The second section lists products provided by each vendor in each region. Section three provides a complete alphabetical listing of vendors including current addresses, key contact personnel, current telephone numbers and, where available, email addresses. A glossary defines technical terms used in this circular.

Our experience in locating active producers of sand, gravel, rock, and soil indicates that, in this industry, names and addresses of small companies especially seem to change frequently. Users of this directory are urged to verify the products currently being offered by each vendor listed and to ensure that these products meet their needs. To provide the most accurate information possible, we plan to update this directory every year.

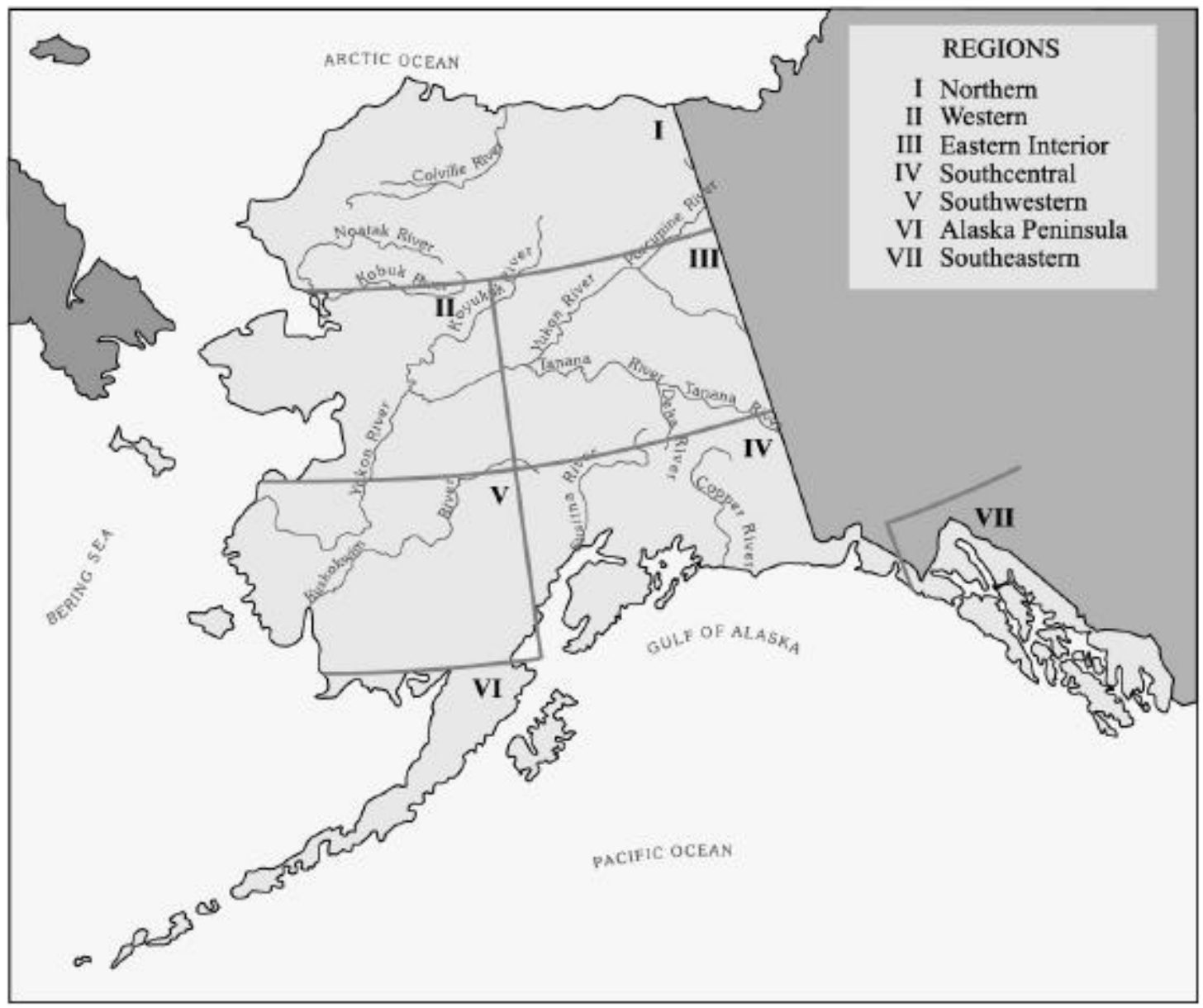

Figure 1. Map showing locations of regional subdivisions of Alaska. 
Table 1. Regional distribution of vendors providing 31 categories of aggregate, rock, and soil products in Alaska (based on 29 responses)

\begin{tabular}{|c|c|c|c|c|c|c|c|c|}
\hline \multirow[b]{2}{*}{ Product } & \multicolumn{7}{|c|}{ Region } & \multirow[b]{2}{*}{ Tota } \\
\hline & Northern & Western & $\begin{array}{l}\text { Eastern } \\
\text { interior }\end{array}$ & $\begin{array}{c}\text { South- } \\
\text { western }\end{array}$ & $\begin{array}{c}\text { Alaska } \\
\text { Peninsula }\end{array}$ & $\begin{array}{l}\text { South- } \\
\text { central }\end{array}$ & $\begin{array}{l}\text { South- } \\
\text { eastern }\end{array}$ & \\
\hline Aggregate & & & 1 & & & & & 1 \\
\hline Armor Rock & & & & & & 1 & & 1 \\
\hline Asphalt & & & 1 & & & 1 & & 2 \\
\hline Asphalt aggregate & & & 2 & & & & 1 & 3 \\
\hline Asphalt concrete & & & & & & 1 & & 1 \\
\hline Base course & & & 1 & & & & & 1 \\
\hline Bituminous gravel and sand & 1 & & & & & 1 & & 2 \\
\hline Concrete & & & & & & 2 & 1 & 3 \\
\hline Concrete aggregate & & & 1 & 1 & & & 1 & 3 \\
\hline Concreteblocks & & & & & & 1 & 1 & 2 \\
\hline Concrete sand & & & & & & 1 & & 1 \\
\hline Crushed asphalt & & & & & & 1 & & 1 \\
\hline Crushed gravel & & & 1 & & & 1 & 1 & 3 \\
\hline Crushed rock & & & 2 & & & 2 & 1 & 5 \\
\hline Drain rock & 1 & & 2 & & & 5 & & 8 \\
\hline Filter sand & & & & & & 1 & & 1 \\
\hline Gravel & & & 2 & & & 7 & & 9 \\
\hline Masonry-mortar sand & & & 1 & & & 1 & 1 & 3 \\
\hline Miscellaneous fill materials & 1 & & 1 & & & 6 & & 8 \\
\hline Oversize & & & & & & 1 & & 1 \\
\hline Pavement products & 1 & & 1 & & & 3 & & 5 \\
\hline Peat & & & & & & 1 & & 1 \\
\hline Pit-run gravel & & & 1 & & & 4 & & 5 \\
\hline Pre-cast concrete & & & 1 & & & & & 1 \\
\hline Ready-mix concrete & & & 3 & 1 & & 1 & 1 & 6 \\
\hline Riprap rock & & & 1 & & & 1 & 1 & 3 \\
\hline Sand & & & 2 & 1 & & 6 & 1 & 10 \\
\hline Screened aggregate & & & 1 & 1 & & 2 & & 4 \\
\hline Shot rock & & & & & & & 1 & 1 \\
\hline Tailings & & & 1 & & & & & 1 \\
\hline Top soil & 1 & & 2 & & & 7 & & 10 \\
\hline No current production reported & & & 1 & & & & 1 & 2 \\
\hline $\begin{array}{l}\text { Number of Respondents* } \\
\text { (*Companies may service } \\
\text { regions })\end{array}$ & 1 & 0 & 8 & 1 & 0 & 15 & 5 & 30 \\
\hline
\end{tabular}




\section{GLOSSARY OF TECHNICAL TERMS}

Aggregate Natural particles, crushed and broken rock, and manmade materials that are graded by size into categories to meet specifications for particular construction uses (Evans, 1978, p. 4).

Armor rock (armor stone) Stone resulting from blasting, cutting, or other methods to obtain pieces heavy enough (generally 1 to 3 tons) to require handling two individual pieces by mechanical means (ASTM, 1988a, Designation D653-87). Used to protect beds, banks, shores, and embankments against intense erosion and scour by running water, tidal currents, and wave action.

Asphalt A dark brown to black cementitious material in which the predominating constituents are bitumens which occur in nature or are obtained in petroleum processing (ASTM, 1988b, Designation D887).

Asphalt aggregate Sized and broken sand and gravel mixed with asphalt in batch plants to form asphalt concrete and road pavements (ASTM, 1988b, Designation D8-87). Dry, clean, fractured particle faces adhere well to bitumen and pack (interlock) efficiently to provide increased concrete and pavement strength (Evans, 1978, p. 4).

Asphalt concrete A composite material that consists essentially of a binding medium (in this case, asphalt) within which are embedded particles or fragments of aggregate (ASTM, 1988b, Designation C12588).

Base course (base) A layer of specified or selected materials of planned thickness constructed on the subgrade or subbase for the purpose of serving one or more functions such as distributing load, providing drainage, minimizing frost action, etc. (ASTM, 1988a, Designation D653-87).

Bitumen A class of black or dark-colored (solid, semisolid, or viscous) cementitious substances, natural or manufactured, composed principally of high molecular weight hydrocarbons, of which asphalts, tars, pitches, and asphaltites are typical (ASTM, 1988b, Designation D8-87).

Bituminous gravel and sand Sand and gravel containing or treated with bitumen (ASTM, 1988b, Designation D8-87).

Concrete A composite construction material made by mixing properly-sized aggregate, a reactive binding medium (portland cement), and water into a slurry (ASTM, 1988b, Designation C125-88). Naturally rounded aggregate particles are desirable because they improve the workability of the mixture when it is poured (Evans, 1978, p. 4).

Concrete aggregate A mixture of appropriately proportioned sand and gravel having a desirably small amount of deleterious substances (weathered feldspars, reactive chert, iron-stone concretions, silt and clay particles, organic matter, friable particles, and detrital coal) to make concrete for specific construction purposes (ASTM, 1988b, Designation C33).

Concrete blocks Block-shaped structural elements made out of concrete.

Concrete sand Fine aggregate used in concrete.

Crushed asphalt The product resulting from the artificial crushing of asphalt pavement.

Crushed gravel The product resulting from the artificial crushing of gravel with substantially all fragments having at least one face resulting from fracture (ASTM, 1988b, Designation C125-88). 
Crushed rock (crushed stone) Reasonably clean, tough, durable rock fragments broken by crushing coarse rock fragments or aggregate so that essentially all particle faces are freshly fractured (ASTM, 1988a, Designation D693-84; Langer, 1988, p. 3).

Drain rock Clean, subrounded rock fragments, principally cobble sized, used as fillings in surface and subsurface drainage structures. Informally called leach rock, bull rock, and sewer rock.

Filter sand Generally silica-rich, clean sand that is poorly graded (well sorted) and permeable (Evans, 1978, p. 5-6). Used extensively in water- and sewage-treatment plants and elsewhere for water conditioning and purification.

Gravel Rounded or subrounded rock particles that pass a 3-in. (76.2-mm) U.S. Standard sieve and are retained on a No. 4 (4.75-mm) U.S. Standard sieve (ASTM, 1988a, Designation D653-87).

Masonry-mortar sand Natural and manufactured sand used in the preparation of mortar. Artificial mortar sand is produced by crushing stone, gravel, or air-cooled blast-furnace slag to ensure suitable particle shape and size gradation. Deleterious substances include friable and lightweight particles and organic impurities, including clastic coal (ASTM, 1988b, Designation C144-87).

Miscellaneous fill materials Manmade mixtures of soils and rock products that are not generally classified by texture, although they commonly contain abundant fine material. May contain considerable organic matter and artificial waste materials (ASTM, 1988a, Designation D653-87). Technically not an aggregate but a basic construction material (Evans, 1978, P. 4).

Oversize Rock or aggregate material that is larger than the specified or desired particle size.

Pavement products Road and airport subbases, bases, and travel surfaces composed of mixtures of asphalt and coarse, crushed aggregate (ASTM, 1988b, Designations D8-87 and D2940-74).

Peat Fibrous organic remains of plants with less than 25 percent by dry weight of noncombustible mineral ash that is preserved in marshy and swampy wetlands (ASTM, 1988a, Designation D2607-69).

Pit-run gravel Gravel or sandy gravel that is used without beneficiation after excavation from a natural deposit.

Pre-cast concrete Variously-shaped pre-made structural elements made of concrete.

Ready-mix concrete Concrete that is freshly mixe $d$ at the vending site (batch plant) and then transported in a continually agitated, slurry state in mixer trucks to the job site for immediate placement (ASTM, 1988b, Designation C94; Dupras, 1989, p. 10).

Riprap rock (riprap stone) Selected hard, angular, quarried stone generally weighing between 25 and 5,400 pounds individually and placed to protect beds, banks, shores, and embankments against wave action, tidal forces, and stream currents (ASTM, 1988a, Designation D653-87; ADOTPF, 1988, p. 305).

Rock Naturally occurring, consolidated materials composed of one or more minerals of the earth's crust (ASTM, 1988a, Designation, C119-87a). Any hard, consolidated materials derived from the earth and usually of relatively small size (Langer, 1988, p. 2).

Sand Particles of rock that pass a No. $4(4.75-\mathrm{mm})$ U.S. Standard sieve and are retained on a No. 200 (75$\mathrm{mm}$ ) U.S. Standard sieve (ASTM, 1988a, Designation D653-87).

Screened aggregate Aggregate that is separated into different classes of particle size by passing it through combinations of fixed or moving screens with standard-sized openings.

Shot rock Rock that has been broken by blasting. 
Soil Unconsolidated sediments made up of solid particles of various sizes and compositions and formed by the physical and chemical breakdown of rock (ASTM, 1988a, Designation D653-87; Jumikis, 1962, p.27). May contain organic matter.

Stone Natural rock material of adequate integrity and quality that it can be quarried and then sawed, cut, split, or otherwise sized, shaped, or finished for specific purposes (ASTM, 1988a, Designation, C119-87a). Natural building stone includes granitic rocks, greenstones, limestones, marbles, massive serpentinite (antigorite), and sandstones.

Tailings Those portions of washed or milled ore material that are regarded as too poor to be treated further for recovery of precious metals. Generally comprises washed gravel (with or without blocks of local rock) or crushed ore rock.

Top soil Generally fine-grained surface soil, frequently including significant organic matter (ASTM, 1988a, Designation D653-87). 


\section{REFERENCES CITED}

Alaska Department of Transportation and Public Facilities, 1988, Standard specifications for highway construction, $601 \mathrm{p}$.

American Society for Testing and Materials, 1988a, 1988 Annual book of ASTM standards, v. 04.08 (soil and rock, building stones, geotextiles): Philadelphia, $951 \mathrm{p}$.

1988b, 1988 Annual book of ASTM standards, v. 04.02 (concrete and aggregates): Philadelphia, 749 p.

Bundtzen, T.K., Fakins, G.R., and Conwell, C.N., 1982, Review of Alaska mineral resources 1981: Alaska Division of Geological \& Geophysical Surveys Annual Report 1981, 48 p., scale 1:3,000,000, 2 sheets.

Bundtzen, T.K., Eakins, G.R., and Conwell, C.N., 1983, Alaska mineral resources 1981-82: Alaska Division of Geological \& Geophysical Surveys Annual Report 1981-82, 153 p., scale 1:2,500,000, 4 sheets.

Bundtzen, T.K., Eakins, G.R., Clough, J.G., Lueck, L.L., Green, C.B., Robinson, M.S., and Coleman, D.A., 1984, Alaska's mineral industry 1983: Alaska Division of Geological \& Geophysical Surveys Special Report 33, 56 p.

Bundtzen, T.K., Eakins, G.R., Green, C.B., and Lueck, L.L., 1986, Alaska's mineral industry 1985: Alaska Division of Geological \& Geophysical Surveys Special Report 39, 68 p.

Bundtzen, T.K., Green, C.B., Deagen, J.R., and Daniels, C.L., 1987, Alaska's mineral industry 1986: Alaska Division of Geological \& Geophysical Surveys Special Report 40, 68 p.

Bundtzen, T.K., Green, C.B., Peterson, R.J., and Seward, A.F., 1988, Alaska's mineral industry 1987: Alaska Division of Geological \& Geophysical Surveys Special Report 41, 69 p.

Bundtzen, T.K., Swainbank, R.C., Clough, A.H., Henning, M.W., and Charlie, K.M., 1996, Alaska's mineral industry 1995: Alaska Division of Geological \& Geophysical Surveys Special Report 50, 72 p.

Bundtzen, T.K., Swainbank, R.C., Clough, A.H., Henning, M.W., and Hansen, E.W., 1994, Alaska's Mineral Industry 1993: Alaska Division of Geological \& Geophysical Surveys Special Report 48, 84 p.

Bundtzen, T.K., Swainbank, R.C., Deagen, J.R., and Moore, J.L., 1990, Alaska's mineral industry 1989: Alaska Division of Geological \& Geophysical Surveys Special Report 44, 100 p.

Bundtzen, T.K., Swainbank, R.C., Wood, J.E., and Clough, A.H., 1991, Alaska's mineral industry 1991: Division of Geological \& Geophysical Surveys Special Report 46, 89 p.

Dupras, Don, 1989, The grandeur of concrete: California Geology, v. 42, no. 1, p. 3-11.

Eakins, G.R., Bundtzen, T.K., Lueck, L.L., Green, C.B., Gallagher, J.L., and Robinson, M.S., 1985, Alaska's mineral industry 1984: Alaska Division of Geological \& Geophysical Surveys Special Report 38, 57 p.

Eakins, G.R., Bundtzen, T.K., Robinson, M.S., Clough, J.G., Green, C.B., Clautice, K.H., and Albanese, M.A., 1983, Alaska's mineral industry 1982: Alaska Division of Geological \& Geophysical Surveys Special Report 31, 68 p.

Evans, J.R., Sand and gravel: U.S. Bureau of Mines Mineral Commodity Profile MCP-23, 22 p. 
Green, C.B., Bundtzen, T.K., Peterson, R.J., Seward, A.F., Deagen, J.R., and Burton, J.E., 1989, Alaska's mineral industry 1988: Alaska Division of Geological \& Geophysical Surveys Special Report 43, 79 p.

Jumikas, A.R., 1962, Soil mechanics: Princeton, D. Van Nostrand Company, 791 p.

Langer, W.H., 1988, Natural aggregates of the conterminous United States: U.S. Geological Survey Bulletin $1594,33 \mathrm{p}$.

Swainbank, R.C., Bundtzen, T.K., and Wood, J.M., 1991, Alaska's mineral industry 1990: Alaska Division of Geological \& Geophysical Surveys Special Report 45, 78 p.

Swainbank, R.C., Bundtzen, T.K., Clough, A.H., and Henning, M.W., 1997, Alaska's mineral industry 1996: Alaska Division of Geological \& Geophysical Surveys Special Report 51, 68 p.

Swainbank, R.C., Bundtzen, T.K., Clough, A.H., Hansen, E.W., and Nelson, M.G., 1993, Alaska's Mineral Industry 1992: Alaska Division of Geological \& Geophysical Surveys Special Report 47, 80 p.

Swainbank, R.C., Bundtzen, T.K., Clough, A.H., Henning, M.W., and Hansen, E.W., 1995, Alaska's Mineral Industry 1994: Alaska Division of Geological \& Geophysical Surveys Special Report 49, 77 p.

Swainbank, R.C., Clautice, K.H., and Nauman, J.L., 1998, Alaska's mineral industry 1997: Alaska Division of Geological \& Geophysical Surveys Special Report 52, 65 p.

Swainbank, R.C., Szumigala, D.J., Henning, M.W., and Pillifant, F.M., 2000, Alaska's mineral industry 1999: Alaska Division of Geological \& Geophysical Surveys Special Report 54, 73 p.

Szumigala, D.J., and Swainbank, R.C., 1999, Alaska's mineral industry 1998: Alaska Division of Geological \& Geophysical Surveys Special Report 54, 78 p. 


\section{SECTION 1 \\ PRODUCT LISTING ${ }^{2}$}

\section{Alaska Peninsula Region}

No respondents.

\section{Eastern Interior Region}

Aggregate

H \& H CONTRACTORS INC.

FAIRBANKS, AK

Asphalt

H \& H CONTRACTORS INC.

FAIRBANKS, AK

Asphalt aggregate

F S \& G AGGREGATE

$\mathrm{H} \& \mathrm{H}$ CONTRACTORS INC.

FAIRBANKS, AK

FAIRBANKS, AK

Base course

H \& H CONTRACTORS INC.

FAIRBANKS, AK

Concrete aggregate

$\mathrm{H} \& \mathrm{H}$ CONTRACTORS INC.

FAIRBANKS, AK

Crushed gravel

F S \& G AGGREGATE

FAIRBANKS, AK

Crushed rock

A.C.E. GENERAL CONTRACTORS, INC.

FAIRBANKS, AK

BROWN'S HILL QUARRY, LLC

FAIRBANKS, AK

Drain rock

BROWN'S HILL QUARRY, LLC

FAIRBANKS, AK

A.C.E. GENERAL CONTRACTORS, INC.

FAIRBANKS, A K

Gravel

FAIRBANKS PRECASTERS, INC.

TRIPLE M CONCRETE

FAIRBANKS, AK

TOK, AK

Masonry-mortar sand

F S \& G AGGREGATE

FAIRBANKS, AK

Miscellaneous fill materials

BROWN'S HILL QUARRY, LLC

FAIRBANKS, AK

Pavement products

PAVING PRODUCTS, INC.

FAIRBANKS, AK

Pit-run gravel

H \& H CONTRACTORS INC.

FAIRBANKS, AK

\footnotetext{
${ }^{2}$ If a product is not listed, it is because there were no respondents reporting production of the material in that region.
} 
Pre-cast concrete

FAIRBANKS PRECASTERS, INC.

FAIRBANKS, AK

Ready-mix concrete

H \& H CONTRACTORS INC.

FAIRBANKS PRECASTERS, INC.

TRIPLE M CONCRETE

FAIRBANKS, AK FAIRBANKS, AK

TOK, AK

Riprap rock

BROWN'S HILL QUARRY, LLC

FAIRBANKS, AK

Sand

H \& H CONTRACTORS INC.

FAIRBANKS, AK

TRIPLE M CONCRETE

TOK, AK

Screened aggregate

F S \& G AGGREGATE

FAIRBANKS, AK

Tailings

A.C.E. GENERAL CONTRACTORS, INC.

FAIRBANKS, AK

Top soil

BROWN'S HILL QUARRY, LLC

H \& H CONTRACTORS INC.

FAIRBANKS, AK

FAIRBANKS, AK

No current production reported

FAIRBANKS SAND AND GRAVEL, INC.

FAIRBANKS, AK

\section{Northern Region}

Bituminous gravel and sand

ALASKA ROAD BUILDERS, INC.

SOLDOTNA, AK

Drain rock

ALASKA ROAD BUILDERS, INC.

SOLDOTNA, AK

Miscellaneous fill materials

ALASKA ROAD BUILDERS, INC.

SOLDOTNA, AK

Pavement products

ALASKA ROAD BUILDERS, INC.

SOLDOTNA, AK

Top soil

ALASKA ROAD BUILDERS, INC.

SOLDOTNA, AK

\section{Southcentral Region}

Armor stone

ALASKA ROADRUNNER

NIKISKI, AK

Asphalt

ALASKA ROCK: A DIVISION OF SUMMIT ALASKA, INC.

ANCHORAGE, AK 
Asphalt concrete

ALASKA ROCK: A DIVISION OF SUMMIT ALASKA, INC.

ANCHORAGE, AK

Bituminous gravel and sand ALASKA ROAD BUILDERS, INC.

SOLDOTNA, AK

Concrete aggregate

COVEY \& SONS, INC.

QUALITY SAND \& GRAVEL

NINILCHIK, AK

WASILLA, AK

Concrete blocks

DAVIS BLOCK CO., INC.

SOLDOTNA, AK

Concrete sand

DAVIS BLOCK CO., INC.

SOLDOTNA, AK

Crushed asphalt

ALASKA ROCK: A DIVISION OF SUMMIT ALASKA, INC.

ANCHORAGE, AK

Crushed gravel

A \& D SERVICES

ANCHOR POINT, AK

Crushed rock

ALASKA ROCK: A DIVISION OF SUMMIT ALASKA, INC.

QUALITY SAND \& GRAVEL

ANCHORAGE, AK

WASILLA, AK

Drain rock

ALASKA ROAD BUILDERS, INC.

SOLDOTNA, AK

ALASKA ROADRUNNER

ALASKA ROCK: A DIVISION OF SUMMIT ALASKA, INC.

DAVIS BLOCK CO., INC.

QUALITY SAND \& GRAVEL

NIKISKI, AK ANCHORAGE, AK

SOLDOTNA, AK

WASILLA, AK

Filter sand

QUALITY SAND \& GRAVEL

WASILLA, AK

Gravel

2 BEARS TRUCKING

BEAVER LOOP SAND \& GRAVEL

ALASKA ROADRUNNER

BIG LAKE LANDSCAPING

COVEY \& SONS, INC.

EAGLE CONTRACTING CORPORATION

PAUL'S SERVICES

SOLDOTNA, AK

KENAI, AK

NIKISKI, AK

BIG LAKE, AK

NINILCHIK, AK

CORDOVA, AK

ANCHOR POINT, AK

Masonry-mortar sand

DAVIS BLOCK CO., INC.

SOLDOTNA, AK

Miscellaneous fill materials

A \& D SERVICES

ALASKA ROAD BUILDERS, INC.

ALASKA ROADRUNNER

ALASKA ROCK: A DIVISION OF SUMMIT ALASKA, INC. HALTNESS CONSTRUCTION, INC.

QUALITY SAND \& GRAVEL

ANCHOR POINT, AK

SOLDOTNA, AK

NIKISKI, AK

ANCHORAGE, AK

VALDEZ, AK

WASILLA, AK 
Oversize

DAVIS BLOCK CO., INC.

SOLDOTNA, AK

Pavement products

ALASKA ROAD BUILDERS, INC.

ALASKA ROCK: A DIVISION OF SUMMIT ALASKA, INC.

QUALITY SAND \& GRAVEL

SOLDOTNA, AK ANCHORAGE, AK

WASILLA, AK

Peat

PAUL'S SERVICES

ANCHOR POINT, AK

Pit-run gravel

A \& D SERVICES

ALASKA ROCK: A DIVISION OF SUMMIT ALASKA, INC.

CASWELL ENTERPRISES

DAVIS BLOCK CO., INC.

ANCHOR POINT, AK

ANCHORAGE, AK

WILLOW, AK

SOLDOTNA, AK

Ready-mix concrete

DAVIS BLOCK CO., INC.

SOLDOTNA, AK

Riprap rock

ALASKA ROADRUNNER

NIKISKI, AK

Sand

A \& D SERVICES

BEAVER LOOP SAND \& GRAVEL

BIG LAKE LANDSCAPING

COVEY \& SONS, INC.

EAGLE CONTRACTING CORPORATION

PAUL'S SERVICES

ANCHOR POINT, AK

KENAI, AK

BIG LAKE, AK

NINILCHIK, AK

CORDOVA, AK

ANCHOR POINT, AK

Screened aggregate

A \& D SERVICES

ANCHOR POINT, AK

DAVIS BLOCK CO., INC.

SOLDOTNA, AK

Top soil

2 BEARS TRUCKING

A \& D SERVICES

ALASKA ROAD BUILDERS, INC.

ALASKA ROADRUNNER

AMERICAN LANDSCAPING CO., INC.

CASWELL ENTERPRISES

PAUL'S SERVICES

SOLDOTNA, AK ANCHOR POINT, AK SOLDOTNA, AK

NIKISKI, AK

ANCHORAGE, AK

WILLOW, AK

ANCHOR POINT, AK

\section{Southeastern Region}

Asphalt aggregate

SOUTHEAST ROADBUILDERS, INC.

HAINES, AK

Concrete

STANFORD MASONRY \& CARPENTRY

HAINES, AK

Concrete aggregate 
SOUTHEAST ROADBUILDERS, INC.

Concrete blocks

CONCRETE CONNECTION, LLC

Crushed gravel

SOUTHEAST ROADBUILDERS, INC.

Crushed rock

SOUTHEA ST ROADBUILDERS, INC.

Masonry-mortar sand

STANFORD MASONRY \& CARPENTRY

Ready-mix concrete

CONCRETE CONNECTION, LLC

Riprap rock

SOUTHEAST ROADBUILDERS, INC.

Sand

SOUTHEAST ROADBUILDERS, INC.

Shot rock

SOUTHEAST BACKHOE SERVICE, INC.

No current production reported

CASCADE SAND AND GRAVEL

\section{Southwestern Region}

Concrete aggregate

BENNETT ENTERPRISES

Ready-mix concrete

BENNETT ENTERPRISES

Sand

BENNETT ENTERPRISES

Screened aggregate

BENNETT ENTERPRISES
HAINES, AK

PETERSBURG, AK

HAINES, AK

HAINES, AK

HAINES, AK

PETERSBURG, AK

HAINES, AK

HAINES, AK

KETCHIKAN, AK

PETERSBURG, AK

DILLINGHAM, AK

DILLINGHAM, AK

DILLINGHAM, AK

DILLINGHAM, AK

\section{Western Region}

No respondents. 


\section{SECTION 2 \\ VENDOR LISTING}

\section{Alaska Peninsula Region}

No respondents.

\section{Eastern Interior Region}

A.C.E. GENERAL CONTRACTORS, INC.

Crushed rock

Drain rock

Tailings

BROWN'S HILL QUARRY, LLC

Crushed rock

Drain rock

Miscellaneous fill materials

Riprap rock

Top soil

F S \& G AGGREGATE

Asphalt aggregate

Concrete Sand

Crushed gravel

Masonry-mortar sand

Screened aggregate

FAIRBANKS PRECASTERS, INC.

Gravel

Pre-cast concrete

Ready-mix concrete

FAIRBANKS SAND AND GRAVEL, INC.

No current production reported

FAIRBANKS, AK

FAIRBANKS, AK

FAIRBANKS, AK

H \& H CONTRACTORS, INC.

Asphalt

Asphalt aggregate

Base course

Concrete aggregate

Pit-run gravel

Ready-mix concrete

Sand

Top soil

PAVING PRODUCTS, INC.

Pavement products

FAIRBANKS, AK

FAIRBANKS, AK

TRIPLE M CONCRETE

Gravel

TOK, AK

Ready-mix concrete

Sand

FAIRBANKS, AK 
ALASKA ROAD BUILDERS, INC.

SOLDOTNA, AK

Bituminous gravel and sand Drain rock

Miscellaneous fill materials

Pavement products

Top soil

\section{Southcentral Region}

2 BEARS TRUCKING

Gravel

Top soil

A \& D SERVICES

Crushed gravel

ANCHOR POINT, AK

Miscellaneous fill materials

Pit-run gravel

Sand

Screened aggregate

Top soil

ALASKA ROAD BUILDERS, INC.

Bituminous gravel and sand

SOLDOTNA, AK

Drain rock

Miscellaneous fill materials

Pavement products

Top soil

ALASKA ROADRUNNER

NIKISKI, AK

Armor stone

Drain rock

Miscellaneous fill materials

Gravel

Riprap rock

Top soil

ALASKA ROCK: A DIVISION OF SUMMIT ALASKA, INC.

ANCHORAGE, A K

Asphalt

Asphalt concrete

Crushed asphalt

Crushed rock

Drain rock

Miscellaneous fill materials

Pavement products

Pit run gravel

AMERICAN LANDSCAPING CO., INC.

Top soil

ANCHORAGE, AK

BEAVER LOOP SAND \& GRAVEL

Gravel

KENAI, AK

Sand 
BIG LAKE LANDSCAPING

BIG LAKE, AK

Gravel

Sand

CASWELL ENTERPRISES

Pit-run gravel

Top soil

COVEY \& SONS, INC.

Concrete aggregate

Gravel

Sand

DAVIS BLOCK CO., INC.

Concrete Blocks

Concrete Sand

Drain rock

Masonry-mortar sand

Oversize

Pit-run gravel

Ready-mix concrete

Screened aggregate

EAGLE CONTRACTING CORPORATION

Gravel

Sand

HALTNESS CONSTRUCTION INC.

Miscellaneous fill materials

PAUL'S SERVICES

Peat

Sand

Top soil

QUALITY SAND \& GRAVEL

Concrete aggregate

Crushed rock

Drain rock

Filter sand

Miscellaneous fill materials

Pavement products

\section{Southeastern Region}

CASCADE SAND AND GRAVEL

PETERSBURG, AK

No current production reported

CONCRETE CONNECTION, LLC

Concrete blocks

Ready-mix concrete

WASILLA, AK

VALDEZ, AK

ANCHOR POINT, AK

PETERSBURG, AK

SOUTHEAST BACKHOE SERVICE, INC.

KETCHIKAN, AK 
Shot rock

SOUTHEAST ROADBUILDERS, INC.

HAINES, AK

Asphalt aggregate

Concrete aggregate

Crushed gravel

Crushed rock

Riprap rock

Sand

STANFORD MASONRY \& CARPENTRY

HAINES, AK

Concrete

Masonry-mortar sand

Southwestern Region

BENNETT ENTERPRISES

Concrete aggregate

Ready-mix concrete

Sand

Screened aggregate

DILLINGHAM, AK

\section{Western Region}

No respondents. 


\section{SECTION 3}

\section{VENDOR ADDRESS LISTING}

2 BEARS TRUCKING

PO Box 1976

Soldotna, AK 99669

Contact: Leo W. Creary

Telephone: (907) 262-5211

twobears@ptialaska.net

\section{A \& D SERVICES}

PO Box 117

Anchor Point, AK 99556-

Contact: Andre Drake

Telephone: (907) 235-7667

Fax: (907) 235-7667

A.C.E. GENERAL CONTRACTORS, INC. 1890 Steese Hwy

Fairbanks, AK 99712

Contact: Stephen Marvin/ Alice Ellingson

Telephone: (907) 457-4700

Fax: (907) 457-7774

ALASKA ROAD BUILDERS, INC.

44482 Frontier Ave.

Soldotna, AK 99669

Contact: Ronald L. Davis

Telephone: (907) 262-9140

Fax: (907) 262-1213

\section{ALASKA ROADRUNNER}

PO Box 7586

Nikiski, AK 99635

Contact: Joseph Ross

Telephone: (907) 776-8070

roadrnnr@alaska.net

ALASKA ROCK:

A DIVISION OF SUMMIT ALASKA, INC.

7828 Lake Otis Pkwy

Anchorage, AK 99507

Contact: Tim Schwanke

Telephone: (907) 344-2644

Fax: (907) 349-5472

TimeSummit-AK.com

AMERICAN LANDSCAPING CO., INC.

130 A St. Loop

Anchorage, AK 99518

Contact: Paul Reynolds

Telephone: (907) 563-3804

Fax: (907) 562-0922

amlandechugach. net

\author{
BEAVER LOOP SAND \& GRAVEL \\ 49758 Island Lake Road \\ Kenai, AK 99611 \\ Contact: Pat Doyle \\ Telephone: (907) 776-8552 \\ Fax: (907) 776-8580

\section{BENNETT ENTERPRISES} \\ PO Box 468 \\ Dillingham, AK 99576 \\ Contact: Ned Bennett \\ Telephone: (907) 842-2270 \\ Fax: (907) 842-2273 \\ BIG LAKE LANDSCAPING \\ PO Box 520354 \\ Big Lake, AK 99652 \\ Contact: Tom Reed \\ Telephone: (907) 892-7660 \\ Fax: (907) 892-7660
}

BROWN'S HILL QUARRY, LLC

PO Box 70668

Fairbanks, AK 99707

Contact: Luther Brice

Telephone: (907) 488-2527

Fax: (907) 488-7185

www.brownshill.com

CASCADE SAND AND GRAVEL

PO Box 1629

Petersburg, AK 99833

Contact: Orrice Bell (owner)/ Linda Reller

Telephone: (907) 772-3604

Fax: (907) 724-4991

CASWELL ENTERPRISES

HC 89 Box 1700

Willow, AK 99688

Telephone: (907) 495-6425

CONCRETE CONNECTION, LLC

PO Box 284

Petersburg, AK 99833

Contact: Cris Morrison

Telephone: (907) 772-3799

Fax: (907) 772-3577 
COVEY \& SONS INC.

PO Box 39124

Ninilchik, AK 99639

Contact: Roger Covey

Telephone: (907) 567-3487

Fax: (907) 567-7442

DAVIS BLOCK CO., INC.

PO Box 126

Soldotna, AK 99669

Contact: Scott Davis/ Rusty Davis

Telephone: (907) 262-5106

Fax: (907) 262-3122

\author{
EAGLE CONTRACTING CORPORATION \\ PO Box 1128 \\ Cordova, AK 99574 \\ Telephone: (907) 424-5702 \\ Fax: (907) 424-3994 \\ F S \& G AGGREGATE \\ PO Box 72844 \\ Fairbanks, AK 99707 \\ Contact: Charlie Chausse \\ Telephone: (907) 452-3834 \\ Fax: (907) 452-3835
}

FAIRBANKS PRECASTERS, INC.

PO Box 75289

Fairbanks, AK 99707

Contact: Mike Dillon

Telephone: (907) 488-9763

Fax: (907) 488-8300

FAIRBANKS SAND AND GRAVEL, INC. PO Box 71350

Fairbanks, AK 99707

Contact: Mary Silvey

Telephone: (907) 452-5336

Fax: (907) 452-2356

silvey@polarnet.com

H \& H CONTRACTORS, INC.

PO Box 60610

Fairbanks, AK 99706-

Contact: Tom Williams

Telephone: (907) 479-2235

Fax: (907) 479-2253

HALTNESS CONSTRUCTION INC.

PO Box 2989

Valdez, AK 99686

Contact: Erik Haltness
Telephone: (907) 835-5418

Fax: (907) 835-3694

PAUL'S SERVICES

PO Box 377

Anchor Point, AK 99556-

Contact: Paul Roderick

Telephone: (907) 235-8405

Fax: (907) 235-8541

kobel@ptialaska.net

PAVING PRODUCTS, INC.

PO Box 80430

Fairbanks, AK 99708

Contact: Cal Morten

Telephone: (907) 452-4903

Fax: (907) 452-6755

QUALITY SAND \& GRAVEL

PO Box 876597

Wasilla, AK 99687

Contact: Emmitt Willson (General Manager)

Telephone: (907) 746-5215

Fax: (907) 746-5226

SOUTHEAST BACKHOE SERVICE, INC. PO Box 9155

Ketchikan, AK 99901

Contact: Martin R. Dillon

Telephone: (907) 225-7029

Fax: (907) 247-7029

SOUTHEAST ROADBUILDERS, INC.

HC60 Box 4800

Haines, AK 99827

Contact: Roger Schnabel

Telephone: (907) 766-2833

Fax: (907) 766-2832

STANFORD MASONRY \& CARPENTRY

PO Box 1021

Haines, AK 99827

Contact: Jim Stanford

Telephone: (907) 767-5558

TRIPLE M CONCRETE

PO Box 128

Tok, AK 99780

Contact: John Martiniuk

Telephone: (907) 883-5303

Fax: (907) 883-5304

triplemeaptalaska_net 


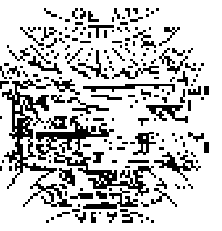

